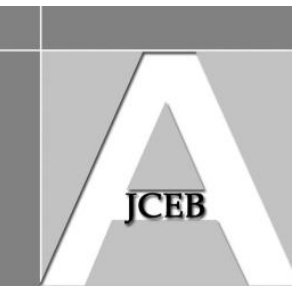

\title{
Mapping Site-based Construction Workers' Motivation: Expectancy Theory Approach
}

\author{
Parviz Ghoddousi, (Iran University of Science and Technology, Iran) \\ Nima Bahrami, (Iran University of Science and Technology, Iran) \\ Nicholas Chileshe, (University of South Australia, Australia) \\ M.Reza Hosseini, (University of South Australia, Australia)
}

\begin{abstract}
The aim of this study is to apply a recently proposed model of motivation based on expectancy theory to site-based workers in construction and confirm the validity of this model for the construction industry. The study drew upon data from 194 site-based construction workers in Iran to test the proposed model of motivation. To this end, the structural equation modelling (SEM) approach based on the confirmatory factor analysis (CFA) technique was deployed. The study reveals that the proposed model of expectancy theory incorporating five indicators (i.e. intrinsic instrumentality, extrinsic instrumentality, intrinsic valence, extrinsic valence and expectancy) is able to map the process of construction workers' motivation. Nonetheless, the findings posit that intrinsic indicators could be more effective than extrinsic ones. This proffers the necessity of construction managers placing further focus on intrinsic motivators to motivate workers.
\end{abstract}

Keywords: Motivation, Expectancy theory, Structural equation modelling, Workers, Construction industry

\section{Introduction}

The construction industry continues to be a key contributor to the gross domestic product (GDP) of most countries and has been identified among the pillars of the economy (Crosthwaite 2000; Horta et al. 2013). Against that backdrop, construction companies have an infamous reputation for low productivity and performance (Dubois \& Gadde 2002) to the extent that the construction industry has been ranked 'at the bottom of all industries' (Chinowsky \& Songer 2011). Hence, the construction industry is in dire need of adopting viable strategies to increase productivity in projects (Abdel-Razek, Abd Elshakour \& AbdelHamid 2007) to enhance competitiveness (Loosemore 2012) due to the extensive effects of globalisation (Olomolaiye \& Price 1989). Devising effective plans to increase productivity has remained a priority for the construction industry (Dainty \& Loosemore 2013). In this context, many research studies have been conducted recently to ascertain the main determinants of productivity in a wide range of countries (Durdyev \& Mbachu 2011; Ghoddousi \& Hosseini 2012; Gudienè, Banaitis \& Banaitiené 2013).

The construction industry is a labour-intensive sector in which human resources are the central contributors to productivity (Sunindijo, Hadikusumo \& Ogunlana 2007; Enshassi et al. 2007a; Kazaz, Manisali \& Ulubeyli 2008; Khaled \& Remon 2013). In this spirit, the effects of the level of motivation of construction workers on their productivity have been widely acknowledged (Olomolaiye 1990; Smithers \& Walker 2000; $\mathrm{Ng}$ et al. 2004; Doloi 2007). In sharp contrast to its prominence, the understanding of motivation in the construction context has hardly gone beyond the initial stages and is deemed limited (Dwivedula \& Bredillet 2010). In particular, little evidence exists to facilitate ascertaining the major factors that influence the motivation of different occupational groups within the construction context (Dainty \& Asad 2005). Likewise, behavioural indicators of workers is an overlooked area in construction management (Cox, Issa \& Koblegard 2005). As a result, studies aimed at mapping the behavioural nature, interrelationships and contours of the motivators of construction workers are rare (Rose \& Manley 2011). On the other hand, models and 
theories developed outside the boundaries of the construction context might not be valid for creating knowledge about the motivators of construction workers (Hazeltine 1976; Ruthankoon \& Ogunlana 2003). It is in this context that conducting studies by adopting and validating different research frameworks, new approaches and methods to further establish the field of motivation in the construction context becomes relevant and necessary (Navarro 2009).

There is evidence postulating that Vroom's (1964) expectancy theory has been the most widely accepted and the most utilised model to explain the behavioural indicators of workers in organisations (Mitchell \& Biglan 1971; Regis, Falk \& Dias 2008). However, many studies have emphasised the necessity of considering the drawbacks of expectancy theory to interpret behavioural aspects (Regis, Falk \& Dias 2008) and have called for further studies to address the lack of external validity of this model (Van Eerde \& Thierry 1996). To address this, a modified version of expectancy theory was proposed and validated by Chiang and Jang (2008) to extend the understanding of employees' motivation.

The review of the literature in the construction context as denoted by Navarro (2009) posited that the validation of the expectancy model in the construction context has been confined to a handful of studies with fragmented focal points. This is exacerbated by the lack of studies on behavioural aspects of the motivation of construction workers as stated in the above section. Moreover, existing studies have used methods based on analysis of variance (ANOVA) and multiple regression to test the validity of expectancy theory whereas application of these methods to validate models would be fraught with particular limitations and errors as stated by Kline (2005).

To fill the described void, this study draws upon the process deployed in Chiang and Jang (2008) to validate the modified version of expectancy theory in the construction context building upon a structural equation modelling (SEM) approach based on a confirmatory factor analysis (CFA) technique. The findings would contribute to this field by shedding some light on the nature of the constructs contributing to the motivation of site-based workers on construction projects. The findings would also be of great importance to practitioners in the industry. Through practitioners' consideration of the findings, workers would be motivated in the way they want which would result in higher levels of motivation and productivity. Moreover, construction managers would be able to implement policies to motivate their workers more effectively through having acquired a deep appreciation of the true wants and needs of their workers.

\section{Workers' Motivation in the Construction Context}

In most of today's companies, workers play a pivotal role in every aspect of conducting business. Likewise, 'keeping them motivated, using them well, and retaining them have become important to competitive advantage, or even a requirement for survival' as stated by Thomas (2009). As a result, one of the ubiquitous directions for investigating increasing workers' productivity has been in relation to enhancing the level of motivation of construction workers (Yi \& Chan 2013). Much evidence has attested to the strong effects of the level of motivation of workers on their productivity within the construction context in a wide range of countries (Olomolaiye 1990; Smithers \& Walker 2000; Ng et al. 2004; Enshassi et al. 2007b; Kazaz, Manisali \& Ulubeyli 2008; Jarkas \& Bitar 2012; Adedokun, Ibironke \& Olanipekun 2013; Khaled \& Remon 2013). All the above discussions confirm the crucial importance of construction managers possessing the knowledge of different aspects of workers' motivation (Mason 1978; Maloney \& McFillen 1983, 1986b; Khan 1993; Zakeri et al. 1997; Ng et al. 2004; Doloi 2007).

The three theories that have been predominantly used by construction researchers to investigate the motivation of workers are Maslow's hierarchy of needs theory, Herzberg's theory of motivation-hygiene and Vroom's expectancy theory (Ogunlana \& Chang 1998; 
Ruthankoon \& Ogunlana 2003; Kazaz, Manisali \& Ulubeyli 2008; Navarro 2009) . There is no doubt that all of these theories have provided construction managers with valuable information. Nevertheless, expectancy theory provides a distinctly superior framework for investigating the motivation concept based on four main considerations:

I. Expectancy theory has been confirmed in many research studies, and the relevant frameworks have gained currency among academia as stated by Khan and Mufti (2012) citing Triandis, Hough and Dunnette (1990). Expectancy theory has been described as the most widely accepted theory among organisational and industrial researchers in a wide range of disciplines (Chiang \& Jang 2008; Liao, Liu \& Pi 2011; Mitchell \& Beach 1976; Regis, Falk \& Dias 2008).

II. As stated by Maloney and McFillen (1983); Kaming et al. (1998); and Kazaz, Manisali and Ulubeyli (2008), expectancy theory is more relevant to the construction industry than the other two theories. This stance is further underpinned when the high level of application of expectancy theory in construction studies is considered (Navarro 2009).

III. There is evidence that has acknowledged the tentative validity of using principles of expectancy theory for investigating the motivation concept in the construction industry, for example, Maloney and McFillen (1986a) and Uwakweh (2006). This makes the objective of this study to investigate a modified version of this theory more tenable.

IV. Expectancy theory falls within the domain of process theories of motivation as opposed to content theories. Process theories concern questions on 'why' and 'how' of workers' motivation (Ruthankoon \& Ogunlana 2003) and describe how motivation occurs (Chiang \& Jang 2008). This makes it more suitable given the objectives of this paper.

\section{Expectancy Theory}

The complexity of the motivation phenomenon requires a contingency approach that takes into account all the influential factors (Koontz \& Weihrich 1993). Expectancy theory was proposed by Victor Vroom (1964) to deal with motivation within working environments through studying the drivers behind individuals' decision making. Expectancy theory builds on a rational flow assuming that effort leads to performance, which in turn leads to primary and secondary outcomes consecutively (Wabba \& House 1974).

Based on expectancy theory, a highly motivational work environment is achievable providing that there is the existence of 'strong expectancies, instrumentalities, and valences' (Maloney \& McFillen 1986a, p. 123). In the same vein, individuals' choices, levels of effort and persistence, and performance are shaped by their beliefs about how well they can perform an activity and the extent to which they value the activity's outcomes (Wigfield \& Eccles 2000). Expectancy theory draws upon three main constructs: expectancy (E), instrumentality (I) and valence (V) as described in Wabba and House (1974). The process through which motivation comes about involves the interactions of these constructs that culminate in generating the motivation force based on the simple calculation illustrated in Equation 1 as depicted in Chiang and Jang (2008, p. 314).

\section{Equation $1 \quad$ Motivation Force $=$ Expectancy $\times$ Instrumentality $\times$ Valence}

In Equation 1, motivation force refers to a force that leads an individual towards certain behavioural alternatives. The theory asserts that people opt for alternatives with the greatest force of motivation (Chiang \& Jang 2008). Expectancy $(E)$ is the belief that one will achieve the performance goals if appropriate efforts are applied. Instrumentality (I) concerns the expectations that rewards will follow when performance requirements are fulfilled. Valence (V) refers to the value that an individual places on the rewards (Regis, Falk \& Dias 2008). 
Among the three constructs of expectancy theory, instrumentality and valence concern outcomes. Thus, any instrumentality or valence falls within either extrinsic or intrinsic categories (Lawler 1971). According to the self-determination theory (SDT) (Deci \& Ryan 1985), different types of motivation are delineated with respect to the difference between the reasons or goals causing the activities. The widely accepted distinction is between intrinsic motivation, which mentions doing something because it is inherently interesting or enjoyable, and extrinsic motivation, which refers to doing something because it leads to a distinguishable outcome and involves activities that are performed as a means to an end (Levesque et al. 2010; Thomas 2009). Seminal studies in the literature have acknowledged that the quality of experience and performance can be very different when one is behaving based on intrinsic reasons in comparison to extrinsic motivators (Ryan \& Deci 2000). As a result, construction managers need an appreciation of extrinsic instrumentality, intrinsic instrumentality, extrinsic valence and intrinsic valence. The aforementioned constructs provide the foundation for this study.

\section{Studies on Motivation within the Construction Industry}

In comparison to the voluminous body of knowledge in the management field (Maloney \& McFillen 1983), motivation is an under-researched area in the construction context (Navarro 2009). One of the earliest thorough studies on the motivation of workers in the construction sector was conducted by Mason (1978) which presented a review of the existing body of knowledge on a wide range of theories of motivation for construction workers. However, some researchers have attempted to apply principles mostly developed outside the construction field to the motivation of occupational groups in the construction industry (Ogunlana \& Chang 1998). As suggested by Navarro (2009), two major criteria provide the basis for classifying the studies conducted on motivation in the construction industry. Firstly, as stated in the above section, many studies (e.g. Kazaz, Manisali \& Ulubeyli 2008) have asserted that three main models have been deployed by construction researchers to describe the concept of motivation in the construction industry. Hence, studies could be classified based on the theory they have deployed to investigate the concept of motivation. Secondly, from another vantage point, one can consider the objectives of studies to delineate the existing treatises on motivation. In this spirit, studies could be classified as: (1) those that attempt to test the motivation theories in the construction industry; and (2) studies aimed at ascertaining the motivators and de-motivators in different countries. For the sake of brevity, the review only includes well-known and recent studies targeting the motivation of site-based workers.

\section{Testing Theories}

Among the studies using Maslow's and Herzberg's theories, some have attempted to test the validity of these theories for the construction context. This includes studies such as Ogunlana and Chang (1998) in which the authors investigated the application of Maslow's theory to construction sites in Thailand. The results indicated that the theory is not truly reflective of the situation and its application should be considered with caution. Moreover, the dependency of motivators on the context and cultural matters was emphasised by the authors. The findings of a later study postulated that 'Herzberg's theory is not entirely applicable to the Thai construction industry' (Ruthankoon \& Ogunlana 2003, p. 340).

The test of expectancy theory for the construction context was performed by Maloney and McFillen (1986a) which resulted in tentative validation of the theory but emphasised the necessity of further investigations on its validity for the construction industry. The theory was likewise tested in Saudi Arabia by Almohawis (1986) where it was generally validated. However, the findings showed glaring differences between workers from different nationalities when it came to effective motivators. 
The results of the literature review and the findings of Navarro's (2009) review reveal that studies intending to test the three major theories are scarce and limited to a handful of treatises in the extant literature. Moreover, Olomolaiye and Price (1989, p. 286) postulated that 'none of the existing theories are satisfactory' for the construction industry which echoes the necessity of further investigation to develop a platform.

\section{Ascertaining Motivators and De-motivators}

One of the first seminal studies in this category is by Borcherding, Samelson and Sebastian (1980) in which the authors addressed the issues of motivation and productivity in US projects. The key motivators were introduced as sufficient design lead time, effective planning of the workface and enhancing the quality of communications. In a similar approach that considered the collective effects of motivation and productivity, Olomolaiye (1990) posited that management of project quality is the main contributor to productivity and motivation on site.

In Iran, Zakeri et al. (1997) and Yisa, Holt and Zakeri (2000) respectively investigated the motivators of workers and site managers in the Iranian construction industry. Both of these studies identified the fairness of pay and financial-related matters as the primary contributors to the motivation of workers and site managers. The prominence of fairness and timeliness concerning payments was also acknowledged in a study undertaken in Indonesia (Kaming et al. 1998). The authors concluded that extrinsic motivators (particularly payment level) would be the case for developing countries. However, they stated that intrinsic values such as belonging and esteem are similar in both developing and developed countries. In the case of Nigeria as shown in the study by Olomolaiye and Ogunlana (1988), the availability of fringe benefits, relationships with colleagues and the nature of tasks were the highest ranked motivators. Conversely, disrespect by supervisors, lack of recognition of effort and pressure for higher productivity without the accompaniment of adequate management policies were the most critical de-motivators. These results were reaffirmed by a later study in Nigeria (Ibironke, Adedokun \& Hungbo 2011) which denoted the importance of welfare in regards to the level of motivation of casual workers.

By comparing the motivators of different occupational work groups, a study in the UK (Dainty \& Asad 2005) posited that unskilled workers are motivated by extrinsic rewards as opposed to professional employees who value intrinsic aspects. Similarly, financial rewards were identified among the key contributors to the motivation of workers in the construction industry in Kuwait as asserted in a recent study by Jarkas and Radosavljevic (2013). The critical effects of financial fairness on workers was also acknowledged in Oman in the recent study by Islam and Khadem (2013). This was in contrast with the findings of an investigation in Turkey (Kazaz, Manisali \& Ulubeyli 2008) that indicated that organisational factors had a stronger effect on workers compared to the financial and socio-psychological aspects of construction projects. Similarly, Doloi's (2007) study conducted in Australia revealed that an encouraging work environment accompanied by incentivised contracts would increase the level of motivation of site-based construction workers.

In a study by Han et al. (2008) which sought to identify the measures to motivate foreign construction workers in South Korea, a flexible system of employment, educational systems, providing an evaluation mechanism followed by incentives and welfare plans were among the key motivators.

Given the differences in the findings of different studies and the controversy observed in the literature in regards to central aspects of workers' motivation, conducting further investigation to further establish the field seems relevant as discussed in previous sections. 


\section{Research Methods}

As stated previously, the procedure and the methods deployed in this paper on the construction industry are built upon the approach of the study by Chiang and Jang (2008) which was conducted on employees in the service industry context.

\section{Hypotheses}

As discussed previously, the major elements of the modified version of expectancy theory comprise five variables, that is, extrinsic instrumentality, intrinsic instrumentality, extrinsic valence and intrinsic valence as well as expectancy (Chiang \& Jang 2008). Hence, the following corresponding hypotheses to validate the model were considered:

- H1: Expectancy has a positive effect on construction workers' motivation.

- H2: Extrinsic instrumentality has a positive effect on construction workers' motivation.

- H3: Intrinsic instrumentality has a positive effect on construction workers' motivation.

- H4: Extrinsic valence has a positive effect on construction workers' motivation.

- H5: Intrinsic valence has a positive effect on construction workers' motivation.

\section{Questionnaire Design}

The five items in the hypotheses were used as umbrella constructs covered by a number of associated measuring items to gauge the perceptions of workers concerning the activity's outcomes and expectations. The variables and measuring items were drawn from the literature particularly by adapting the items used by Uwakweh (2006) and Chiang and Jang (2008). This comprised three measurement items for the expectancy of workers and 13 items to measure instrumentality items including eight pertaining to extrinsic instrumentalities (i.e. rewards) and five relevant to intrinsic instrumentalities (i.e. good feelings as the outcomes of performance). In addition, eight items were used to measure extrinsic valences and five to gauge intrinsic valences. Motivation force as in Equation 1 was measured utilising four measures. All items used to measure the constructs of the model are illustrated in Table 1.

\section{Hypotheses' Tests}

The testing of hypotheses was performed using the structural equation modelling (SEM) approach which deployed confirmatory factor analysis (CFA) due to the proven capabilities of these methods and techniques for testing models as stated in Kline (2005); Schreiber et al. (2006); and Chiang and Jang (2008). The AMOS software package was used to test the hypothesised relationships of construction workers in relation to expectancy theory.

\section{Data Collection and Sample Population}

Having a population of over 10 million (i.e. 1/7 of Iran's population), Tehran is among the most populated capitals in the world and is Iran's largest city (Nasrabadi et al. 2008). Due to the concentration of a wide range of socio-economic opportunities, workers from all occupations and from other regions of the country migrate to Tehran in search of work (Roudsari \& Ghodsi 2005). Hence, Tehran would be representative of a pool of a wide range of construction workers from various backgrounds.

Construction workers from 20 construction sites located in Tehran were targeted. All projects selected for this study were large residential buildings located in Iran and all contractors had a Grade 2 licence based on the classification of contractors in Iran, that is, they were from the group of large companies in the country (see Tabassi, Ramli \& Bakar 2012)). Questionnaires were administered to at least 15 randomly selected workers at each of the 20 selected projects by approaching each worker individually. The data collection procedure ultimately resulted in 194 duly completed surveys which were used for final analysis. It should be noted that this sample size (less than 200) is deemed sufficient albeit medium for conducting SEM and CFA methods according to Kline (2005). The data collection process lasted for around nine months and was finalised in November 2010. 


\begin{tabular}{|c|c|c|c|}
\hline Measurement items & $\mathrm{MS}^{1}$ & Std. Dev & $\mathrm{CV}^{2}$ \\
\hline Expectancy & 3.57 & & \\
\hline $\begin{array}{l}\text { If I put more effort into my job, my productivity will improve } \\
\text { significantly }\end{array}$ & 3.65 & 0.80 & 21.92 \\
\hline If I work very hard, my job performance will significantly improve & 3.54 & 0.78 & 22.03 \\
\hline $\begin{array}{l}\text { If I put more effort into my job, I will definitely be regarded as an } \\
\text { effective employee }\end{array}$ & 3.51 & 0.81 & 23.08 \\
\hline $\begin{array}{l}\text { Extrinsic instrumentality } \\
\text { If I perform my tasks well, it will certainly yield: }\end{array}$ & 3.58 & & \\
\hline Receiving good pay and monetary bonuses & 3.62 & 0.90 & 24.86 \\
\hline Having more authority & 3.85 & 0.77 & 20.00 \\
\hline Getting a better work assignment & 3.73 & 0.81 & 21.72 \\
\hline Getting chances to learn new things & 3.54 & 0.81 & 22.88 \\
\hline Having more employment opportunities with other contractors & 3.36 & 0.89 & 26.49 \\
\hline Getting job promotion & 3.32 & 0.77 & 23.19 \\
\hline Praise from my manager & 3.58 & 0.76 & 21.23 \\
\hline Having job security & 3.61 & 0.86 & 23.82 \\
\hline $\begin{array}{l}\text { Intrinsic instrumentality } \\
\text { If I perform my tasks well, it will certainly yield: }\end{array}$ & 3.97 & & \\
\hline Handing over more responsibility/control over my job & 4.13 & 0.72 & 17.43 \\
\hline Taking on more challenging tasks & 3.67 & 0.75 & 20.44 \\
\hline Feelings of accomplishment & 4.01 & 0.72 & 17.96 \\
\hline Feeling better about myself & 4.04 & 0.72 & 17.82 \\
\hline Having more opportunities to develop my skills and abilities & 3.98 & 0.73 & 18.34 \\
\hline Extrinsic valence & 3.90 & & \\
\hline Good payments & 3.93 & 0.74 & 18.83 \\
\hline Praise from manager & 4.09 & 0.74 & 18.09 \\
\hline Authority & 3.98 & 0.77 & 19.35 \\
\hline More employment opportunities & 3.69 & 0.88 & 23.85 \\
\hline Job promotion & 3.93 & 0.74 & 18.83 \\
\hline Job security & 3.66 & 0.92 & 25.14 \\
\hline Learn new things & 4.04 & 0.81 & 20.05 \\
\hline Better work assignment & 3.85 & 0.76 & 19.74 \\
\hline Intrinsic valence & 3.99 & & \\
\hline More responsibility/control on job & 4.26 & 0.68 & 15.96 \\
\hline More challenging tasks & 3.54 & 0.86 & 24.29 \\
\hline Feelings of accomplishment & 4.06 & 0.74 & 18.23 \\
\hline Feeling good about myself & 4.07 & 0.69 & 16.95 \\
\hline Development of skills and abilities & 4.04 & 0.73 & 18.07 \\
\hline Work motivation & 3.67 & & \\
\hline \multicolumn{4}{|l|}{ When I am strongly motivated, I will certainly } \\
\hline Put in more effort on the job & 3.80 & 0.84 & 22.11 \\
\hline Perform my tasks at higher quality & 3.74 & 0.88 & 23.53 \\
\hline Work more productively & 3.50 & 0.80 & 22.86 \\
\hline Be eager to get involved in my tasks & 3.65 & 0.70 & 19.18 \\
\hline
\end{tabular}

Table 1 Construction workers' statistical responses to measurement items and constructs (original and revised models)

Notes: ${ }^{1}$ Mean score based on 5 -point Likert scale where $1=$ Strongly Disagree; $2=$ Disagree; $3=$ Neutral; $4=$ Agree; and $5=$ Strongly Agree.

${ }^{2} \mathrm{CV}=$ coefficient of variation. The items $(\mathrm{n}=8)$ in red represent the items that were removed from the modified measurement instrument.

Ghoddousi, P et al (2014) 'Mapping site-based construction workers' motivation: Expectancy theory approach', Australasian Journal of Construction Economics and Building, 14 (1) 60-77 


\section{Results}

\section{Profile of Respondents}

With regard to age, $70 \%$ of respondents were younger than 30 denoting the dominance of young workers in the Iranian construction context as stated in previous studies (Zakeri et al. 1996). Iran has one of the youngest populations in the world according to the Statistical Centre of Iran (2011) report on the National Population and Housing Census of Iran: the largest proportion of the population is in the category of '21-30 years'. One-third of the respondents (37\%) had completed guidance school and only $17 \%$ of the respondents had high school qualifications. This indicated that construction workers in Iran still have low levels of literacy as acknowledged in previous studies (Tabassi \& Bakar 2009; Zakeri et al. 1996) which is also the case for most developing countries (Alkilani, Jupp \& Sawhney 2013). Furthermore, construction workers usually do not have salaried and secure job contracts (Doloi 2007), have minimal education and work for low wages (Alkilani, Jupp \& Sawhney 2013). This is the case in Iran where construction workers face many challenges (e.g. family struggles) due to low income (Tabassi \& Bakar 2009).

The abovementioned demographic information facilitates defining the corresponding motivational issues of Iranian construction workers against the background of their age, level of education, low income and concomitant challenges that are envisaged for such conditions.

\section{Descriptive Analyses}

Descriptive analyses comprising computation of the weighted mean, represented by the mean scores, standard deviation (SD) and coefficient of variation (CV) were conducted for each of measurement items in Table 1. These results reflected how each item was scored by workers. In this regard, intrinsic valence, intrinsic instrumentality and extrinsic valence had the highest scores.

\section{Validity Analysis (Confirmatory Factor Analysis)}

The AMOS software package was used to compute the necessary fit indices using the maximum likelihood estimate for the initial model. This comprised the original 33 measurement items administered to the group of respondents. To test the validity of the constructs in the model, each measurement item was loaded on its corresponding construct whilst allowing for constructs to be correlated as in the method suggested in the authoritative work by Anderson and Gerbing (1988). The indices of the model and the associated values indicative of an acceptable level of fit for each index are captured in Table 2. It should be mentioned that many goodness-of-fit indicators are available for validating CFA models. The indices selected for this study are those recommended by the study of Schreiber et al. (2006) for one time analysis.

As shown in Table 2, the test of the overall model fit yielded an $x^{2}$ of 633.302 with 545 degrees of freedom and a $p$-value of less than 0.05 . While most parameters suggested a good fit, the values of two fit indices, that is, the goodness-of-fit index (GFI) and the root mean square error of approximation (RMSEA) were not acceptable against the recommended values as highlighted in Table 2 Fit indices for the initial structural measurement modelThis reflected the necessity to revise the model.

Revising the model involved excluding the following eight items owing to their low loadings using Marsh and Balla's (1994) criteria: (1) getting job promotion; (2) praise from my manager; (3) having job security (extrinsic instrumentality); (4) job promotion; (5) job security; (6) learn new things; (7) better work assignment (extrinsic valence); and (8) development of skills and abilities (intrinsic valence). Hence, the eight mentioned items (as highlighted in Table 1) were deleted from the original instrument to fit the construction workers' responses. The indices of the revised model indicated a noticeable improvement 
resulting in a good-fit revised model. The model indices had values for the following items that all fell within the acceptable ranges shown in Table 2. This included $x^{2} / d f=1.071$, $\mathrm{RMSEA}=0.019, \mathrm{GFI}=0.907$ and $\mathrm{CFI}=0.983$.

\begin{tabular}{|c|c|c|c|c|}
\hline Fit index & Study & $\begin{array}{l}\text { Recommended } \\
\text { values }\end{array}$ & Source & Decision \\
\hline$d f$ & 545 & & & \\
\hline$x^{2}$ & 633.302 & & & \\
\hline$x^{2} / d f$ & 1.162 & $\leq 3.00$ & (Bagozzi \& Yi 1988) & Acceptable fit \\
\hline$p$-value & 0.000 & $<0.05$ & & Acceptable fit \\
\hline GFI & 0.855 & $\geq 0.90$ & $\begin{array}{l}\text { (Bostic, Rubio \& Hood 2000; } \\
\text { Marsh \& Balla 1994) }\end{array}$ & Unacceptable fit \\
\hline CFI & 0.937 & $\geq 0.90$ & $\begin{array}{l}\text { (Bostic, Rubio \& Hood 2000; } \\
\text { Marsh \& Balla 1994) }\end{array}$ & Acceptable fit \\
\hline RMSEA & 0.092 & $\leq 0.08$ & (Browne \& Cudeck 1993) & Unacceptable fit \\
\hline
\end{tabular}

Table 2 Fit indices for the initial structural measurement model

Notes: $\mathrm{x}^{2}=$ chi-square test; $\mathrm{x}^{2} / \mathrm{df}=$ normed chi-square; GFI = goodness-of-fit index; CFI = comparative fit index, RMSEA = root mean square error of approximation; $n=194 ;{ }^{*} p<0.05 ;{ }^{* *} p<0.01$

\section{Reliability and Convergent and Discriminant Validity}

The results of confirmatory factor analysis (CFA) present the associated parameters and indices used to test the reliability, and convergent and discriminant validity of the model are illustrated in Table 3.

\begin{tabular}{|c|c|c|c|c|c|c|}
\hline Construct $^{1}$ & Indicators & $\begin{array}{c}\text { Convergent } \\
\text { Factor } \\
\text { loadings }\end{array}$ & $\begin{array}{c}\text { Cronbach's } \\
\text { alpha ( } \alpha)\end{array}$ & $\begin{array}{l}\text { Composite } \\
\text { reliability } \\
\text { (CR) }\end{array}$ & $\begin{array}{c}\text { Average } \\
\text { variance } \\
\text { extracted } \\
\text { (AVE) }\end{array}$ & $\begin{array}{c}\text { Standard } \\
\text { error }\end{array}$ \\
\hline \multirow[t]{3}{*}{ EXPEC } & EXPEC1 & 0.63 & 0.683 & 0.700 & 0.44 & 0.146 \\
\hline & EXPEC2 & 0.65 & & & & 0.144 \\
\hline & EXPEC3 & 0.70 & & & & 0.132 \\
\hline \multirow[t]{5}{*}{ EXTIN } & EXTIN1 & 0.56 & 0.692 & 0.705 & 0.325 & 0.186 \\
\hline & EXTIN2 & 0.58 & & & & 0.192 \\
\hline & EXTIN3 & 0.50 & & & & 0.191 \\
\hline & EXTIN4 & 0.64 & & & & 0.179 \\
\hline & EXTIN5 & 0.56 & & & & 0.185 \\
\hline \multirow[t]{5}{*}{ INTIN } & INTIN1 & 0.67 & 0.760 & 0.770 & 0.41 & 0.134 \\
\hline & INTIN2 & 0.50 & & & & 0.133 \\
\hline & INTIN3 & 0.66 & & & & 0.134 \\
\hline & INTIN4 & 0.72 & & & & 0.138 \\
\hline & INTIN5 & 0.61 & & & & 0.135 \\
\hline \multirow[t]{4}{*}{ EXTVA } & EXTVA1 & 0.61 & 0.700 & 0.707 & 0.377 & 0.148 \\
\hline & EXTVA2 & 0.58 & & & & 0.154 \\
\hline & EXTVA3 & 0.68 & & & & 0.144 \\
\hline & EXTVA4 & 0.58 & & & & 0.159 \\
\hline \multirow[t]{4}{*}{ INTVA } & INTVA1 & 0.70 & 0.717 & 0.73 & 0.40 & 0.131 \\
\hline & INTVA2 & 0.62 & & & & 0.133 \\
\hline & INTVA3 & 0.66 & & & & 0.134 \\
\hline & INTVA4 & 0.55 & & & & 0.138 \\
\hline \multirow[t]{4}{*}{ WOMOT } & WOMOT1 & 0.71 & 0.771 & 0.79 & 0.48 & 0.129 \\
\hline & WOMOT2 & 0.73 & & & & 0.131 \\
\hline & WOMOT3 & 0.70 & & & & 0.108 \\
\hline & WOMOT4 & 0.62 & & & & 0.094 \\
\hline
\end{tabular}

Table 3 Results of the confirmatory factor analysis (CFA)

Notes: ${ }^{1}$ EXPEC = expectancy; EXTIN = extrinsic instrumentality; INTIN = intrinsic instrumentality; EXTVA = extrinsic valence; INTVA = intrinsic valence; WOMOT = work motivation

Ghoddousi, P et al (2014) 'Mapping site-based construction workers' motivation: Expectancy theory approach', Australasian Journal of Construction Economics and Building, 14 (1) 60-77 
To test the internal consistency reliability, Cronbach's alpha coefficient $(\alpha)$ and composite reliability (CR) (Fornell \& Larcker 1981) were used to assess the reliability of the scale as presented in Table 3. The Cronbach's alpha values for the six constructs ranged from $0.683-$ 0.771 . Therefore, the reliability and convergent validity of the measurements were secured and deemed appropriate for SEM to be conduction. Moreover, all values for composite reliability met the threshold of $\geq 0.7$ as stated in Hair et al. (1998).

Convergent validity can be assessed from the measurement model by determining whether each indicator's estimated maximum likelihood loading on the underlying construct is significant $(>0.4)$. The results of the correlations between constructs versus variances extracted are shown in Table 4. Discrimination between the constructs is established since the average variance extracted (AVE) values for each construct (see Table 3 ) exceeded squared correlations between pairs of constructs (Table 4) as instructed in Fornell and Larcker (1981).

\begin{tabular}{|l|l|l|l|l|l|l|}
\hline \multicolumn{1}{|c|}{ Construct } & \multicolumn{1}{|c|}{$\mathbf{1}$} & \multicolumn{1}{|c|}{$\mathbf{2}$} & \multicolumn{1}{|c|}{$\mathbf{3}$} & \multicolumn{1}{|c|}{$\mathbf{4}$} & \multicolumn{1}{|c|}{$\mathbf{5}$} & $\mathbf{6}$ \\
\hline 1. Expectancy & 1 & & & & & \\
\hline 2. Extrinsic instrumentality & $0.33^{* * *}$ & 1 & & & & \\
\hline 3. Intrinsic instrumentality & $0.29^{* * *}$ & $0.374^{* * *}$ & 1 & & & \\
\hline 4. Intrinsic valence & $0.141^{*}$ & $0.24^{* *}$ & $0.207^{\star *}$ & 1 & & \\
\hline 5. Extrinsic valence & $0.408^{\star * *}$ & $0.324^{* * *}$ & $0.331^{* * *}$ & $0.333^{* * *}$ & 1 & \\
\hline 6. Work motivation & $0.463^{* * *}$ & $0.413^{* * *}$ & $0.403^{\star * *}$ & $0.377^{* * *}$ & $0.545^{* * *}$ & 1 \\
\hline
\end{tabular}

Table 4 Correlations between constructs versus variances extracted Notes: ${ }^{*} p<0.05,{ }^{* *} p<0.01,{ }^{* * *} p<0.001 ; \mathrm{n}=194$

\section{Structural Model}

Standardised path coefficients as reported in Table 5 and further illustrated in Figure 1 The structural model

were calculated to examine the study's hypotheses.

\begin{tabular}{|l|l|l|l|}
\hline \multicolumn{1}{|c|}{ Hypothesised path (from $\rightarrow$ to) } & \multicolumn{1}{|c|}{$\begin{array}{c}\text { Standardised } \\
\text { path } \\
\text { coefficients } \boldsymbol{\beta}\end{array}$} & t-value & $\begin{array}{c}\text { Hypothesis } \\
\text { test outcome }\end{array}$ \\
\hline H1: Expectancy $\rightarrow$ Work motivation & 0.32 & $2.50^{* *}$ & Supported \\
\hline H2: Extrinsic instrumentality $\rightarrow$ Work motivation & 0.235 & $2.44^{* *}$ & Supported \\
\hline H3: Intrinsic instrumentality $\rightarrow$ Work motivation & 0.12 & $2.35^{*}$ & Supported \\
\hline H4: Extrinsic valence $\rightarrow$ Work motivation & 0.24 & $2.17^{*}$ & Supported \\
\hline H5: Intrinsic valence $\rightarrow$ Work motivation & 0.31 & $2.70^{* *}$ & Supported \\
\hline
\end{tabular}

Table 5 Path coefficients of the model (based on Chiang \& Jang [2008])

Notes: ${ }^{1 * *}$ Correlation is significant at the 0.01 level (2-tailed); and ${ }^{*}$ correlation is significant at the 0.05 level (2tailed)

The correlation estimate reported in Table 4 between motivation and expectancy showed a high score of $0.463(\rho<0.001)$. In addition, expectancy significantly correlated to extrinsic instrumentality $(r=0.33, \rho<0.01)$, intrinsic instrumentality $(r=0.29, \rho<0.001)$ and intrinsic valence $(r=0.408, \rho<0.001)$, respectively. However, the correlation between expectancy and extrinsic valence did not seem to be very significant $(r=0.141, \rho<0.05)$. Thus, based on the results presented in Table 5, the standardised path coefficient and $t$-value supported hypothesis $\mathrm{H} 1(\beta=0.32, t(194)=2.50, \rho<0.01)$. As a result, it is inferred that expectancy and motivation are highly correlated and expectancy has a positive effect on workers' 
motivation. Furthermore, according to the results, expectancy has the highest effect on motivation.

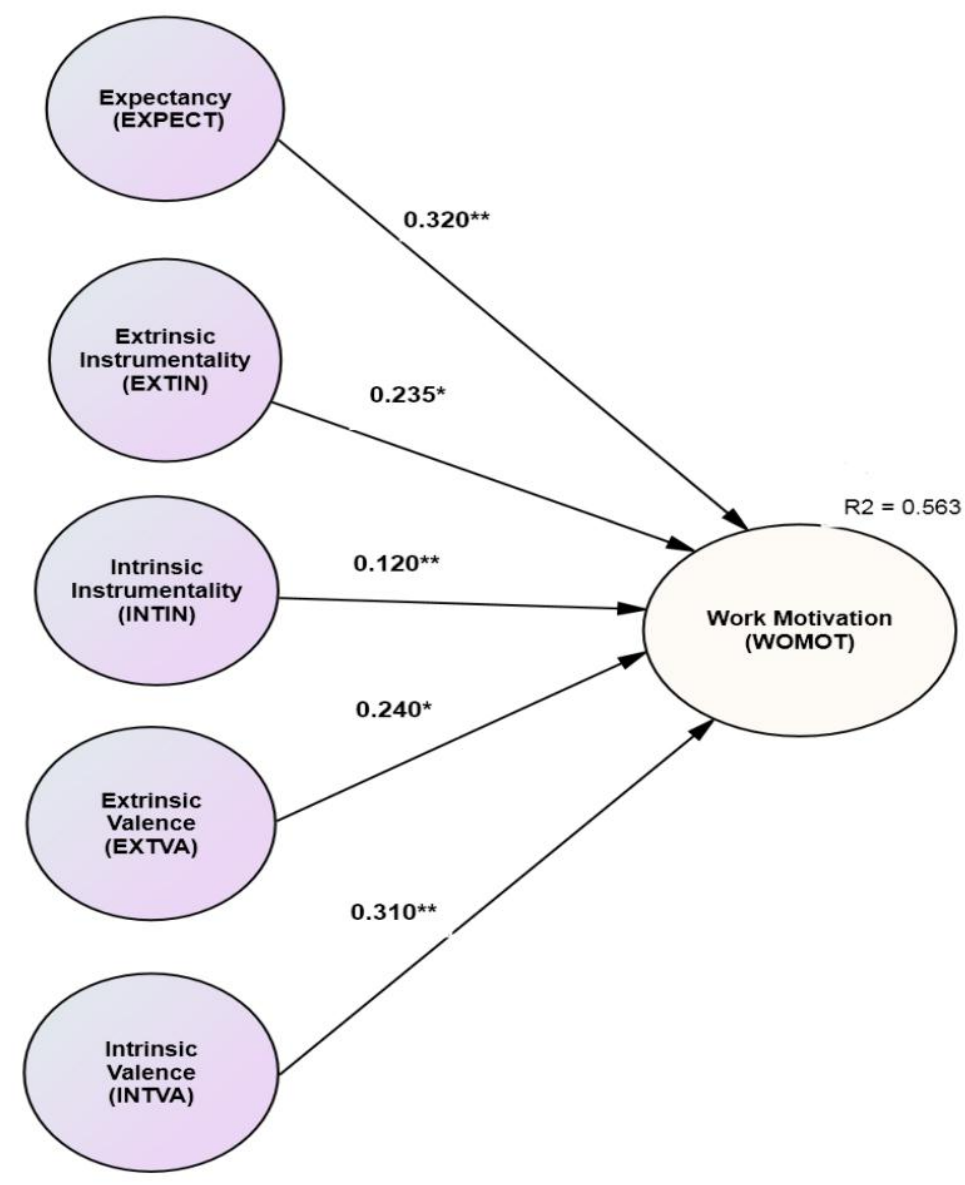

Figure 1 The structural model

Notes: ${ }^{*} p<0.05,{ }^{* *} p<0.01,{ }^{* * *} p<0.001$

In addition, it can be asserted from Table 5 that the hypothesis associated with the path from EXTIN to WOMOT $(\mathrm{H} 2)$ was significant $(\beta=0.235, t(194)=2.44, \rho<0.01)$. The path from intrinsic instrumentality to work motivation (INTIN to WOMOT), that is, H3, was also supported and significant $(\beta=0.12, t(194)=2.35, \rho<0.05)$. Similarly, the path from extrinsic valence to work motivation (EXTVA to WOMOT), namely, $\mathrm{H} 4$, was equally significant $(\beta=0.235, t(194)=2.17, \rho<0.05)$. This was the case for the hypothesis concerning the path from intrinsic valence to work motivation (INTVA to WOMOT), thus H5 $(\beta=0.31, t(194)=2.70, \rho<0.01)$ was also supported.

\section{Discussion}

It can be confirmed from the confirmatory factor analysis (CFA) results that expectancy theory is able to explain construction workers' motivation in a developing country such as Iran and would explain the attitudes of Iranian construction labourers. This aligned with previous studies attesting to the validity of expectancy theory for the construction context in the USA (i.e. Maloney \& McFillen 1986a; Uwakweh 2006) and contradicts Olomolaiye and Price's (1989) study in which expectancy theory is regarded as unsatisfactory for this context. In addition, the findings suggest that modifying expectancy theory (i.e. using expectancy, extrinsic and intrinsic instrumentality, and extrinsic and intrinsic valence indicators) would facilitate an understanding of the nature of the determinants of construction workers' motivation. This is discussed in the following sections. 
As can be seen from Figure 1 The structural model

, the exogenous variables in the model explained high and adequate amounts of variance of WOMOT $\left(R^{2}=0.563\right)$. According to the approach by Tenenhaus et al. (2005), the $R^{2}$ values can be divided based on the path coefficients and correlations between the dependent and explanatory variables as shown on the values captured in Table 6.

\begin{tabular}{|l|c|c|c|c|}
\hline \multicolumn{1}{|c|}{ Block } & $\boldsymbol{\beta}$ & $\boldsymbol{r}$ & Contribution to $\boldsymbol{R}^{\mathbf{2}}(\%)$ & Ranking \\
\hline Intrinsic valence & 0.310 & 0.545 & 30.55 & 1 \\
\hline Expectancy & 0.320 & 0.463 & 26.79 & 2 \\
\hline Extrinsic instrumentality & 0.235 & 0.413 & 17.55 & 3 \\
\hline Extrinsic valence & 0.240 & 0.377 & 16.36 & 4 \\
\hline Intrinsic instrumentality & 0.120 & 0.403 & 8.74 & 5 \\
\hline
\end{tabular}

Table 6 Explanation of workers' motivational drivers

Notes: Workers' motivation $\beta=$ standardised path coefficients; $r=$ correlation coefficient

Based on the values in Table 6, it can be concluded that intrinsic valence and expectancy were the most important variables in the prediction of workers' motivation, contributing $30.55 \%$ and $26.79 \%$ of $R^{2}$, respectively. The high proportion of expectancy of workers was observed in studies in different contexts and conducted decades ago (e.g. Maloney \& McFillen 1986a). The authors of that paper indicated that expectancy is the same for construction workers even with different attributes regardless of the environmental influences. Similarly, Uwakweh (2006) stated that expectancy is merely affected by the gender of workers. This is understandable as expectancy has roots in experience, selfconfidence and the perceived difficulty of performing the assigned tasks (Chiang \& Jang 2008), thus it is hardly affected by the environment.

As a result, it could be inferred that apart from the context and the working environment, construction workers generally believe that their efforts will definitely result in desired performance. Furthermore, it could be proffered that expectancy would not be a determinant of site-based workers' motivation. This is due to this item's level being high enough as implied by Maloney and McFillen (1986b), denoting the salience of paying more attention to the other elements of motivation as discussed below.

Pay-related rewards used to be regarded as the most valued motivators within the construction context (Olomolaiye \& Price 1989; Rose \& Manley 2011) with this being attested as applicable to the case of construction workers (Ogunlana \& Chang 1998). Likewise, previous studies in Iran (Zakeri et al. 1996) identified this as being the staple of workers' motivation which was justified by their low income (Tabassi \& Bakar 2009). This is fathomable for developing countries according to the explanation provided in Mansfield \& Odeh (1991, p. 96) which stated that: 'when incomes are static or falling owing to high inflation, the importance of money as a motivator increases in relation to other types of reward'.

Nevertheless, the findings of this study highlight the absolute superiority of intrinsic valence over extrinsic valence in terms of motivating construction workers as has been observed in other developing countries such as Turkey (Kazaz, Manisali \& Ulubeyli 2008). As proposed in the mentioned paper, extrinsic valence will remain an effective motivator within the construction industry; however, it no longer has the main role in motivating workers in the construction industry. 
As proposed by Rose \& Manley (2011), in the contemporary construction context, extrinsic valence such as financial incentives does not automatically assure higher levels of motivation. Extrinsic valence incentives may no longer be sufficient and should be accompanied by the provision of intrinsic valence to workers should it be effective in increasing their motivation levels. This highlights the prominent role of the managerial aspect of construction projects in enhancing the level of motivation of workers or 'the quality of site management' as postulated by Kazaz, Manisali and Ulubeyli (2008).

The low weight of extrinsic valence in motivating workers could be justified by drawing upon two explanations. Firstly, as asserted by Kazaz, Manisali and Ulubeyli (2008), workers are generally not happy with their payments regardless of the amount, thus payment could not be regarded as a motivator. Secondly, due to the lack of skilled workers in the Iranian construction industry (Tabassi \& Bakar 2009), construction workers can easily shift from one site to another. This is facilitated by the way in which industrial relations are governed in the Iranian construction industry where a major proportion of site-based workers work casually with no obligatory contractual arrangements (Roudsari \& Ghodsi 2005) forcing them to continue working in unsatisfactory jobs. Therefore, they opt to quit any job in which they are not happy with the payment level instead of continuing to work with low levels of motivation.

The low weight of extrinsic instrumentality means that workers do not believe that achieving high performance will definitely culminate in good pay, bonuses, etc. This can also be understood by considering the rampant pay issues on most Iranian construction sites where workers are usually paid based on payments made by clients to the contractor which are highly irregular and mostly delayed (Ghoddousi \& Hosseini 2012). As a result, workers do not expect to receive what they deserve in terms of extrinsic rewards. These conditions could be the reason behind the low weight of extrinsic instrumentality which is a general rule stated by Chiang and Jang (2008).

The lowest weight belonged to intrinsic instrumentality meaning that workers do not expect to receive intrinsic incentives such as empowerment, more control or more opportunities. This could be due to the traditional approach used by site managers to increase workers' performance by the expedient of 'having punishments associated with non-performance' (Doloi 2007). In sharp contrast to this policy, many authoritative psychological studies on human nature (e.g. Wabba \& House 1974) have posited that intrinsic aspects of motivation are more effective and powerful in motivating workers. Moreover, implementing such policies does not require the allocation of more financial resources by construction managers (Uwakweh 2006) which makes it a viable option for construction projects.

\section{Conclusions}

The findings of this study reaffirm the validity of expectancy theory for the construction industry. Furthermore, this opens the door to utilise the modified version of this model to throw some light on the nature of construction workers' motivation in a developing country such as Iran. The findings wholeheartedly attest to the superiority of intrinsic motivators over extrinsic ones for motivating construction workers. This study also highlights that fact that expectancy cannot play an effective role for workers as it is generally at an acceptable level. The focus should be on increasing the items associated with the intrinsic instrumentality of workers. In other words, construction managers should pay more attention to implementing strategies in which workers will be satisfied intrinsically as the result of high performance.

The findings also stress the prominence of financial incentives and rewards associated with extrinsic outcomes for workers as prerequisites and the foundation of any system geared towards motivating construction workers.

The findings of this study might be applicable to developing countries. However, any generalisation for other contexts should be approached with caution because data were 
collected from one country with some specific conditions. Moreover, there is a chance of bias with this study's responses as workers might have intended to conceal their true financial intentions and needs. To address these limitations, future studies should consider incorporating more indicators to more effectively clarify the nature of motivators. In addition, a similar approach should be taken to conducting the study in different countries by collecting data from more diverse samples to reduce the potential for error.

\section{References}

Abdel-Razek, RH, Abd Elshakour, MH \& Abdel-Hamid, M. (2007) 'Labor productivity: benchmarking and variability in Egyptian projects', International Journal of Project Management, 25 (2), 189-197.

Adedokun, OA, Ibironke, OT \& Olanipekun, AO. (2013) 'Vulnerability of Motivation Schemes in Enhancing Site Workers' Productivity for Construction Industry's Sustainability in Nigeria', International Journal of Sustainable Construction Engineering and Technology, 4 (1), 21-30.

Alkilani, SZ, Jupp, J \& Sawhney, A. (2013) 'Issues of construction health and safety in developing countries: a case of Jordan', Australasian Journal of Construction Economics and Building, 13 (3), 141-156.

Almohawis, SA. (1986) 'Motivation of Construction Workers in Saudi Arabia: An Expectancy Theory Approach', Unpublished PhD thesis, University of Texas, Austin, Ann Arbor.

Anderson, JC \& Gerbing, DW. (1988) 'Structural equation modeling in practice: A review and recommended two-step approach', Psychological Bulletin, 103 (3), 411-423.

Bagozzi, RP \& Yi, Y. (1988) 'On the evaluation of structural equation models', Journal of the Academy of Marketing Science, 16 (1), 74-94.

Borcherding, JD, Samelson, NM \& Sebastian, SM. (1980) 'Improving motivation and productivity on large projects', Journal of the Construction Division, 106 (1), 73-89.

Bostic, TJ, Rubio, DM \& Hood, M. (2000) 'A validation of the subjective vitality scale using structural equation modeling', Social Indicators Research, 52 (3), 313-324.

Browne, MW \& Cudeck, Y. (1993) ' Alternative Ways of Assessing Model Fit', in KA Bollen \& JS Long (eds), Testing structural equation models, 136-162.

Chiang, C-F \& Jang, S. (2008) 'An expectancy theory model for hotel employee motivation', International Journal of Hospitality Management, 27 (2), 313-322.

Chinowsky, P \& Songer, A. (2011) 'Introduction', In P Chinowsky \& A Songer (eds), Organization management in construction, Spon Press, New York.

Cox, R, Issa, R \& Koblegard, K. (2005) 'Management's Perception of Key Behavioral Indicators for Construction', Journal of Construction Engineering and Management, 131 (3), 368-376.

Crosthwaite, D. (2000) 'The global construction market: a cross-sectional analysis', Construction Management and Economics, 18 (5), 619-627.

Dainty, ARJ \& Asad, S. (2005) 'Job Motivational Factors for Disparate Occupational Groups within the UK Construction Sector: A Comparative Analysis', Journal of Construction Research, 6 (2), 223-236.

Dainty, A \& Loosemore, M. (2013) Human Resource Management in Construction Projects, Routledge.

Deci, EL \& Ryan, RM. (1985) Intrinsic motivation and self-determination in human behavior, Springer.

Doloi, H. (2007) 'Twinning Motivation, Productivity and Management Strategy in Construction Projects', Engineering Management Journal, 19 (3), 30-40. 
Dubois, A \& Gadde, L-E. (2002) 'The construction industry as a loosely coupled system: implications for productivity and innovation', Construction Management and Economics, 20 (7), 621-631.

Durdyev, S \& Mbachu, J. (2011) 'On-site Labour Productivity of New Zealand Construction Industry: Key Constraints and Improvement Measures', Australasian Journal of Construction Economics and Building, 11 (3), 18-33.

Dwivedula, R \& Bredillet, CN. (2010) 'Profiling work motivation of project workers', International Journal of Project Management, 28 (2), 158-165.

Enshassi, A, Mohamed, S, Mayer, P \& Abed, K. (2007a) 'Benchmarking masonry labor productivity', International Journal of Productivity and Performance Management, 56 (4), 358-368.

Enshassi, A, Mohamed, S, Mustafa, ZA \& Mayer, PE. (2007b) 'Factors affecting labour productivity in building projects in the Gaza Strip', Journal of Civil Engineering and Management, 13 (4), 245-254.

Fornell, C \& Larcker, DF. (1981) 'Evaluating structural equation models with unobservable variables and measurement error', Journal of Marketing Research, 39-50.

Ghoddousi, P \& Hosseini, MR. (2012) 'A Survey of the Factors Affecting the Productivity of Construction Projects in Iran', Technological and Economic Development of Economy, 18 (1), 99-116.

Gudienè, N, Banaitis, A \& Banaitienè, N. (2013) 'Evaluation of critical success factors for construction projects - an empirical study in Lithuania', International Journal of Strategic Property Management, 17 (1), 21-31.

Hair, JF, Anderson, RE, Tatham, RL \& Black, WC. (1998) Multivariate data analysis, Upper Saddle River, NJ: Prentice Hall.

Han, S, Park, S, Jin, E, Kim, H \& Seong, Y. (2008) 'Critical Issues and Possible Solutions for Motivating Foreign Construction Workers', Journal of Management in Engineering, 24 (4), 217-226.

Hazeltine, CS. (1976) 'Motivation of construction workers', Journal of the Construction Division, 102 (CO3), 497-510.

Horta, IM, Camanho, AS, Johnes, J \& Johnes, G. (2013) 'Performance trends in the construction industry worldwide: an overview of the turn of the century', Journal of Productivity Analysis, 39 (1), 89-99.

Ibironke, O, Adedokun, O \& Hungbo, A. (2011) 'Drivers and Challenges of Motivation for Casual Workers on Construction Sites', Journal of Emerging Trends in Economics and Management Sciences, 2 (5), 413-417.

Islam, MA \& Khadem, MMRK. (2013) 'Productivity determinants in Oman construction industry', International Journal of Productivity and Quality Management, 12 (4), 426-448.

Jarkas, A \& Bitar, C. (2012) 'Factors Affecting Construction Labor Productivity in Kuwait', Journal of Construction Engineering and Management, 138 (7), 811-820.

Jarkas, A \& Radosavljevic, M. (2013) 'Motivational Factors Impacting the Productivity of Construction Master Craftsmen in Kuwait', Journal of Management in Engineering, 29 (4), 446-454.

Kaming, PF, Olomolaiye, PO, Holt, GD \& Harris, FC. (1998) 'What motivates construction craftsmen in developing countries? A case study of Indonesia', Building and Environment, 33 (2-3), 131-141.

Kazaz, A, Manisali, E \& Ulubeyli, S. (2008) 'Effect of basic motivational factors on construction workforce productivity in Turkey', Journal of Civil Engineering and Management, 14 (2), 95-106. 
Khaled, M \& Remon, F. (2013) 'Factors Influencing Construction Labor Productivity in Egypt', Journal of Management in Engineering, doi:10.1061/(ASCE)ME.1943-5479.0000168.

Khan, MS. (1993) 'Methods of motivating for increased productivity', Journal of Management in Engineering, 9 (2), 148-156.

Khan, W \& Mufti, EO. (2012) 'Effect of Compensation on Motivating Employees in Public and Private Banks of Peshawar, Journal of Basic and Applied Scientific Research, 2 (5), 46164623.

Kline, RB. (2005) Principles and practice of structural equation modeling, The Guilford Press, New York.

Koontz, H \& Weihrich, H. (1993) Management: a global perspective, McGraw-Hill, New York. Lawler, EE. (1971) Pay and organizational effectiveness: A psychological view, McGraw-Hill New York,

Levesque, C, Copeland, KJ, Pattie, MD \& Deci, EL. (2010) 'Intrinsic and Extrinsic Motivation', in Peterson, P, Baker, E \& McGaw, B (eds), International Encyclopedia of Education (Third Edition), Elsevier, Oxford, 618-623.

Liao, H-L, Liu, S-H \& Pi, S-M. (2011) 'Modeling Motivations for Blogging: An Expectancy Theory Analysis', Social Behavior and Personality, 39 (2), 251-264.

Loosemore, M. (2012) 'Impediments to reform in the Australian Building and Construction Industry', Australasian Journal of Construction Economics and Building, 3 (2), 1-8.

Maloney, WF \& McFillen, JM. (1983) 'Research needs in construction worker performance', Journal of Construction Engineering and Management, 109 (2), 245-254.

Maloney, WF \& McFillen, JM. (1986a) 'Motivation in unionized construction', Journal of Construction Engineering and Management, 112 (1), 122-136.

Maloney, WF \& McFillen, JM. (1986b) 'Motivational implications of construction work', Journal of Construction Engineering and Management, 112 (1), 137-151.

Mansfield, NR \& Odeh, NS. (1991) 'Issues affecting motivation on construction projects', International Journal of Project Management, 9 (2), 93-98.

Marsh, HW \& Balla, J. (1994) 'Goodness of fit in confirmatory factor analysis: The effects of sample size and model parsimony', Quality \& Quantity, 28 (2), 185-217.

Mason, A. (1978) Worker motivation in building (occasional paper No.19), Institute of Building, Berkshire, UK.

Mitchell, TR \& Biglan, A. (1971) 'Instrumentality theories: Current uses in psychology', Psychological Bulletin, 76 (6), 432.

Mitchell, TR \& Beach, LR. (1976) 'A review of occupational preference and choice research using expectancy theory and decision theory', Journal of Occupational Psychology, 49 (4), 231-248.

Nasrabadi, T, Hoveidi, H, Bidhendi, GN, Yavari, AR \& Mohammadnejad, S. (2008) 'Evaluating citizen attitudes and participation in solid waste management in Tehran, Iran', Journal of Environmental Health, 71 (5), 30.

Navarro, E. (2009) 'A Review of Maslow, Herzberg and Vroom in the Construction Industry over the Last 25 Years', In Proceedings of 25th Annual Conference, ARCOM (Association of Researchers in Construction Management).

$\mathrm{Ng}$, ST, Skitmore, RM, Lam, KC \& Poon, AW. (2004) 'Demotivating factors influencing the productivity of civil engineering projects', International Journal of Project Management, 22 (2), 139-146.

Ogunlana, SO \& Chang, WP. (1998) 'Worker motivation on selected construction sites in Bangkok, Thailand', Engineering, Construction and Architectural Management, 5 (1), 61-81. 
Olomolaiye, PO \& Ogunlana, SO. (1988) 'A survey of construction operative motivation on selected sites in Nigeria', Building and Environment, 23 (3), 179-185.

Olomolaiye, PO \& Price, ADF. (1989) 'A review of construction operative motivation', Building and Environment, 24 (3), 279-287.

Olomolaiye, PO. (1990) 'An evaluation of the relationships between bricklayers' motivation and productivity', Construction Management and Economics, 8 (3), 301-313.

Regis, HP, Falk, JA \& Dias, SC. (2008) 'Expectancy Theory', in SR Clegg \& JR Bailey (eds), International Encyclopedia of Organization Studies, Sage Publications, Inc., Thousand Oaks, CA.

Rose, T \& Manley, K. (2011) 'Motivation toward financial incentive goals on construction projects', Journal of Business Research, 64 (7), 765-773.

Roudsari, BS \& Ghodsi, M. (2005) 'Occupational injuries in Tehran', Injury, 36 (1), 33-39.

Ruthankoon, R \& Ogunlana, SO. (2003) 'Testing Herzberg's two-factor theory in the Thai construction industry', Engineering, Construction and Architectural Management, 10 (5), 333-341.

Ryan, RM \& Deci, EL. (2000) 'Intrinsic and Extrinsic Motivations: Classic Definitions and New Directions', Contemporary Educational Psychology, 25 (1), 54-67.

Schreiber, JB, Nora, A, Stage, FK, Barlow, EA \& King, J. (2006) 'Reporting structural equation modeling and confirmatory factor analysis results: A review', The Journal of Educational Research, 99 (6), 323-338.

Smithers, GL \& Walker, DH. (2000) 'The effect of the workplace on motivation and demotivation of construction professionals', Construction Management \& Economics, 18 (7), 833-841.

Statistical Centre of Iran (2011) 2011 National Population and Housing Census of Iran Report (available at: http://www.amar.org.ir ).

Sunindijo, R, Hadikusumo, B \& Ogunlana, S. (2007) 'Emotional Intelligence and Leadership Styles in Construction Project Management', Journal of Management in Engineering, 23 (4), 166-170.

Tabassi, AA \& Bakar, A. (2009) 'Training, motivation, and performance: The case of human resource management in construction projects in Mashhad, Iran', International Journal of Project Management, 27 (5), 471-480.

Tabassi, AA, Ramli, M \& Bakar, AHA. (2012) 'Effects of training and motivation practices on teamwork improvement and task efficiency: The case of construction firms', International Journal of Project Management, 30 (2), 213-224.

Tenenhaus, M, Vinzi, VE, Chatelin, Y-M \& Lauro, C. (2005) 'PLS path modeling', Computational Statistics \& Data Analysis, 48 (1), 159-205.

Thomas, KW. (2009) Intrinsic Motivation at Work: What Really Drives Employee Engagement, Berrett-Koehler Publishers, San Francisco, CA.

Triandis, HC, Hough, LM \& Dunnette, MD. (1990) Handbook of industrial and organizational psychology, 2nd edn, Consulting Psychologists Press, Palo Alto, CA.

Uwakweh, BO. (2006) 'Motivational Climate of Construction Apprentice', Journal of Construction Engineering and Management, 132 (5), 525-532.

Van Eerde, W \& Thierry, H. (1996) 'Vroom's expectancy models and work-related criteria: A meta-analysis', Journal of Applied Psychology, 81 (5), 575.

Vroom, VH. (1964) Work and motivation, Wiley, New York.

Wabba, MA \& House, RJ. (1974) 'Expectancy Theory in Work and Motivation: Some Logical and Methodological Issues', Human Relations, 27 (2), 121-147. 
Wigfield, A \& Eccles, JS. (2000) 'Expectancy-value theory of achievement motivation', Contemporary Educational Psychology, 25 (1), 68-81.

Yi, W \& Chan, A. (2013) 'Critical Review of Labor Productivity Research in Construction Journals', Journal of Management in Engineering, doi:10.1061/(ASCE)ME.19435479.0000194.

Yisa, SB, Holt, GD \& Zakeri, M. (2000) 'Factors affecting management motivation in the Iranian construction industry: a survey of site managers', In Proceedings of 16th Annual Conference, ARCOM (Association of Researchers in Construction Management), 6-8 September.

Zakeri, M, Olomolaiye, PO, Holt, GD \& Harris, FC. (1996) 'A survey of constraints on Iranian construction operatives' productivity', Construction Management and Economics, 14 (5), 417-426.

Zakeri, M, Olomolaiye, P, Holt, G \& Harris, F. (1997) 'Factors affecting the motivation of Iranian construction operatives', Building and Environment, 32 (2), 161-166. 